\title{
Efficacy and tolerance of policresulen in the treatment of the genitourinary syndrome of menopause
}

\begin{abstract}
Objective: To evaluate the efficacy and tolerance of policresulen in the treatment of genitourinary syndrome of menopause

Materials and methods: Controlled clinical trial, randomized, masked "double-blind". 321 women aged 40 or older, diagnosed with genitourinary syndrome of menopause, who had engaged in sexual activity in the last six weeks, and had visited a Level III private health care institution in Armenia, Quindío (Colombia), from February to December 2018 were included. Women under hormonal treatment and with absolute contraindications for the use of policresulen were excluded. Women were randomly assigned to two treatments: 117 received policresulen and 114 placebos (control group). Efficacy and tolerance were evaluated, as well as the adverse effects presented during the 12 weeks of follow-up. A nonstrict consecutive sampling was made.
\end{abstract}

Results: The dose of policresulen was effective for symptom control, showing an efficacy of $76.92 \%$, $(n=90 / 117)$, versus $38.59 \%$, $(n=44 / 117)$ in the placebo group, with a statistically significant difference $(\mathrm{p}=0.003)$. Policresulen tolerance was adequate in $91.45 \%$ of women, compared to $92.98 \%$ of placebos, without statistically significant difference $(\mathrm{p}=0.375)$. The incidence of adverse effects was as follows: local burning sensation (4.27\%), discharge of mucosal tissue fragments $(2.56 \%)$ and vaginal candidiasis $(1.7 \%)$ in the policresulen group, compared with, $5 \%, 1.75 \%$ and $1.75 \%$, respectively, in the placebo group. There were fewer adverse effects in the placebo group, but there was no statistically significant difference between groups ( $89.74 \%$ vs. 92,$1 ; \mathrm{p}=0,27)$.

Conclusion: The use of policresulen in women with genitourinary syndrome of menopause is effective for the management of the most frequent symptomatology. Although it is true that it is not the first therapeutic line of treatment, it should be considered in women for whom estrogen therapy is contraindicated or in those who do not wish to receive it. There was a low presence of adverse effects at the dose used, however, these were tolerable and did not require the interruption of the medication.

Keywords: dyspareunia, menopause, atrophy, lubrication, Efficacy, drug tolerance
Volume 3 Issue 3 - 2019

\section{Franklin José Espitia De La Hoz \\ Ginecología y Obstetricia, Universidad Militar Nueva Granada, Colombia}

Correspondence: Franklin José Espitia De La Hoz, Ginecología y Obstetricia, Universidad Militar Nueva Granada, Sexología Clínica, Máster en Sexología, Educación y asesoramiento sexual, Universidad de Alcalá de Henares, Uroginecología/ FUCS - Hospital de San José/Unicamp, Brasil, Clínica Sexológica, Armenia, Quindío, Colombia, Email espitiafranklin@hotmail.com

Received: June 14, 2019 | Published: June 26, 2019

\section{Introduction}

For the last five years, new terminology has been introduced to describe atrophic vaginitis, atrophic Volvo-vaginitis or postmenopausal vulvo-vaginal atrophy; thus the new term genitourinary syndrome of menopause (GSM), which is defined as "a set of symptoms and signs associated with a decrease in estrogen and other sex steroids that involve changes in the labia majora or minora, clitoris, vestibule/ introitus, vagina, urethra and bladder." The modification was required because the first terms did not include most of the constellation of signs and symptoms present during this specific moment in women's life, especially because they do not consider the symptoms associated to the lower urinary tract. In addition, it has been seen that not everyone is comfortable talking about the vulva and/or the vagina (health professionals or patients), which is why the term atrophy has an inadequate connotation. ${ }^{1,2}$ The prevalence of GSM in Colombia is around $51.61 \% .^{2}$ It causes vaginal dryness, dyspareunia, vaginal irritation, genital pruritus (burning sensation), sinusorrhagia and urinary symptoms (most uncomfortable for women). ${ }^{1-3} 71.87 \%$ of symptomatic women have three vulvo-vaginal symptoms and/or urinary tract symptoms; ${ }^{2}$ but only $64 \%$ complain of painful sexual intercourse and loss of libido, which is why $58 \%$ avoid sexual intercourse, ${ }^{4}$ especially coitus. The WHO estimates 1,200 million women will be over 50 years of age by $2030 .{ }^{5}$ Consequently, if GMS causes negative vaginal problems, as well as frequent emotional and sexual disorders, leading to adverse effects on the quality of life of postmenopausal women, ${ }^{2,6,7}$ it is critical that health professionals understand menopause, and know how to prevent its catastrophic effects.

The treatment and management of GMS should be individualized for each woman, considering the severity of the symptoms, the effect on the quality of life, the risk of recurrence and personal preferences. The options highlight both hormonal and non-hormonal therapies, with estrogen therapy being the first therapeutic line for symptom relief. ${ }^{8,9}$ The information that is available regarding the use of nonhormonal therapies is endless, and the results vary. Policresulen is a solution indicated for the topical treatment of inflammations or of cervico-vaginal tissue lesions. It coagulates the necrotic or pathogenically altered tissue and promotes the scaliness of said tissues. It is a polymolecular organic acid; a condensation polymer of metacresol sulfonic acid bonded to methylene bridges with different 
chain lengths, making it a large molecule, that cannot be absorbed into the systemic circulation; it as a localized effect in the affected tissue where it is applied, and does not affect healthy tissues. It stimulates the regeneration and reepithelization processes, and has astringent properties, granting it healing, anti-inflammatory and antihemorrhagic properties. In addition, due to its high acidity $(\mathrm{pH}<0.6)$ it as a high bactericidal and self-sterilizing power, eliminating the possibility of bacterial multiplication. ${ }^{10,11}$ This study seeks to learn about the effectiveness and tolerability of policresulen; its objective is to evaluate the efficacy and tolerance of policresulen in the treatment of genitourinary syndrome of menopause (GSM), as a nonhormonal alternative, in a sample of postmenopausal women from the Department of Quindío, Colombia.

\section{Materials and methods}

Design and population Controlled, randomized, masked "doubleblind" clinical trial, conducted from February 1, 2018 to December 31, 2018 in Armenia, capital of the department of Quindío (located in the central region of Colombia). The study was carried out at Clinica Sexológica, a private healthcare reference center, an academic center, that takes care of people pertaining to private and social security health care plans, in Colombia. Sample size: considering a confidence level of $95 \%$, with an error margin of $3 \%$ and an expected proportion of $5 \%$, the estimated calculated sample was of 203 women. Patient selection was done through a simple random sample, with a table of random numbers. The sampling was consecutive non-strict. Women older than or equal to 40 years, diagnosed with genitourinary syndrome of menopause, who had engaged in sexual activity in the last six weeks were included. Women under hormonal treatment and with absolute contraindications for the use of policresulen were excluded.

\section{Procedure}

Women were selected from the population of patients assigned to the menopause and climacteric program of the institution. The information was collected by nurses from the research team, duly trained in the process of recruiting patients and completing forms. Women were surveryed during their medical appointment with the specialist, after verifying inclusion and exclusion criteria. If women fulfilled the selection criteria and accepted to participate in the study, they were informed about the objectives of the research and were asked to fill out the informed consent and the confidentiality agreement for information management. Once women signed the informed consent, they were given a self-report questionnaire where socio-demographic characteristics, sexual and reproductive health data, symptoms, background and clinical examination data were recorded. The specialist evaluated the presence of GMS according to the symptomatology reported by the woman. The diagnosis was made with the finding of one or more of the following symptoms: vulvo-vaginal symptoms (burning, decreased vaginal lubrication, dyspareunia, pain, coital discomfort, itching, burning, postcoital bleeding and vaginal dryness) or lower urinary tract symptoms (dysuria, bladder tenesmus, nocturia, frequency, recurrent urinary tract infections, urinary urgency, urinary incontinence, postcoital infection and decreased urethral urine flow). ${ }^{1,2}$ Once the diagnosis was made, the nature of their clinical condition was explained to each woman, and therapeutic alternatives were offered (local policresulene or the use of placebo). The placebo was characterized as a pure and inactive substance, a water-based type of lubricant.

\section{Intervention}

All patients were prescribed treatment. They were randomized to receive one of the two preparations (policresulen or placebo). The medications were presented in identical containers; neither the women nor the researcher knew which solution each woman received. Each patient was given administration instructions and the quantity required until the following appointment. The therapy assignment was made based on a table of random numbers, in blocks of 6 subjects.

\section{Evaluation}

For eleven months, 231 women with a diagnosis of menopausal genitourinary syndrome were recruited. All the patients included in the research were evaluated during a twelve-week treatment period, with four evaluation controls. They were followed up every four weeks until completing the follow-up cycle. In each appointment they filled in a questionnaire on efficacy, tolerance and adverse events potentially related to the substance that had been administered. Likewise, they were provided with the medication required for continuation of the treatment. Patients were prescribed a full dosage of 5 grams of policresulen. They were prescribed a daily vaginal gel application for 4 weeks, at bedtime; and an application twice a week (three days interval) as a maintenance therapy, until completing the 12 weeks. In each follow-up visit, adherence to treatment was monitored, and the patients had to rate the effectiveness by a percentage evaluation of the main signs and symptoms of GMS [urinary symptoms, sinusorrhagia, genital pruritus (burning sensation), irritation vaginal, dyspareunia and vaginal dryness]] according to prevalence in recent Colombian publications, ${ }^{2,3}$ and of their own symptoms upon admission.

Symptoms were classified according to severity as follows: Severe (greater than $75 \%$ ), Moderate (greater than $25 \%$ and less than $75 \%$ ) and Mild (less than $25 \%$ ). The evaluation of the effectiveness was made by means of rating the percentage of decrease of the symptoms, using a subjective evaluation table designed for the purpose and that offered the following reports: Excellent (decrease greater than 75\%), Good (decrease greater than $50 \%$ and less than $75 \%$ ), Moderate (decrease greater than $25 \%$ and less than $50 \%$ ) and Poor (decrease less than $25 \%$ ). The efficacy was established by the difference in improvement for the values associated to a decrease in symptomatology in both groups at the end of the treatment. Tolerance was evaluated in each follow up visit by looking for the absence or presence of symptoms or signs associate to adverse reactions; it was classified as Excellent (there were no adverse effects), Good (one adverse effect), Regular (two adverse effects) or Bad (three or more adverse effects). These data were evaluated by the researcher, through direct questioning; the responses of each follow up visit, as well as the adverse effects, were recorded in the clinical history and in a special format designed by the researchers.

\section{Measured variables}

Socio-demographic variables such as (age, race, marital status, occupation, level of studies, height, weight, body mass index (BMI), alcohol intake, smoking, sedentary lifestyle); age of menarche and menopause, evolution of time of menopause, history of hysterectomy, salpingectomy and gynecological or urological surgery; variables of sexual and reproductive health: age of onset of sexual life, masturbation, oral sex, vaginal or anal intercourse, average frequency of monthly sexual relations, time of cohabitation with a partner, history of sexual abuse or sexual violence in marriage and a couple with 
sexual dysfunction were considered. The percentage of evaluation of the efficacy and tolerance of the substances administered, the presence of adverse effects, as well as the time of symptom improvement were also evaluated.

\section{Statistical analysis}

The collected data were analyzed statistically using the Six Sigma statistical program. The applied tests were the " $\mathrm{t}$ " of Student for comparison of socio-demographic parameters, the Wilcoxon test for the comparison of non-parametric paired data, the Mann-Whitney U for the nonparametric data (unpaired), the test for $\chi^{2}$ and the ANOVA (analysis of variance), taking in all cases the $p$ value $<0.05$ as the limit of statistical significance.

\section{Ethical aspects}

The study was approved by the Ethics and Research Commission of Clinica Sexólogica. The signature of the informed consent was requested for participation in the study, and the confidentiality of the information was guaranteed.

\section{Results}

Of a total of 279 women, with symptomatology associated to the genitourinary syndrome of menopause, 258 women were included $(92.47 \%)$ and seven $(2.71 \%)$ refused to participate. Of the remaining 251 women who met the selection criteria, a total of $11(4.38 \%)$ did not provide all the required information, another $5(1.99 \%)$ withdrew before completing the 12-week follow-up and were rejected 4 $(1.59 \%)$ due to poor treatment compliance. In this way, a total of 231 $(92.03 \%)$ women were considered for the final analysis; 117 received policresulen and 114 received placebo. In the total population, the mean age of the participants was $56.72 \pm 8.35$ years (range between 40 and 84 ), and that of the couple was $59.86 \pm 7.42$ years (range between 42 and 93). They were mostly Hispanic, Catholic, employed, middle class, stable union, high level of schooling, urban origin belonging to private health care plans. The age of onset of menopause was $49.31 \pm 8.37$ ) years (range between 42 and 54), with a mean menopause duration of 7.94 \pm 5.27 years (range between 3 and 12). The socio-demographic characteristics were similar in both groups, with no statistically significant differences (Table 1). The mean age of menarche was $12.58 \pm 0.79$ years (range between 9 and 15 years). The reported age for first sexual intercourse was on average $18.62 \pm 4.18$ years (range between 15 and 24) The age of the first delivery was a mean of $19.35 \pm 5.27$ years (range between 15 and 27), with a median of 3 children (range between 0 and 7$) .29 .43 \%(n=68 / 231)$ reported more than 20 years living with a couple.

A total of $78.35 \%(n=181 / 231)$ of the participants stated they had active sexual lives and $10.38 \%(n=24 / 231)$ used sex toys, $68.83 \%$ expressed they felt pain during intercourse, $77.48 \%$ affirmed there had been a loss of libido, while $59.74 \%$ expressed that they avoided sexual intercourse using all kinds of excuses. Masturbation is considered a common practice in $44.58 \%(\mathrm{n}=103 / 231)$ of the participants. A total of $98.26 \%$ manifested that sexual activity was important in their life; $41.12 \%$ affirmed that sex was fundamental in their life, yearning for a coital frequency of 1 to 4 times per week (median 2 times a week); however, $35.82 \%$ were concerned that their children were aware they were sexually active. $93.07 \%$ considered sexual activity as essential for marriage success. To the question, ¿how many times did you have sex last month? (period defined as the period of the previous thirty days), $41.12 \%(n=95 / 231)$ reported a median of 4 sexual intercourses per month (range between 0 and 9). The most frequent sexual practice was vaginal intercourse $(100 \%)$, and the least frequent was anal intercourse (11.68\%). 94.37\% ( $\mathrm{n}=218 / 231)$ of the women stated that their partner had some sexual dysfunction. $17.74 \%$ $(n=41 / 231)$ reported having suffered some form of sexual violence throughout their lives, while $22.51 \%(n=52 / 231)$ reported violence or sexual abuse by the couple, after the onset of menopause, secondary to the refusal to voluntarily consent to sexual activity. The prevalence of the severity of the symptoms of GMS in the policresulen group was Severe in $70.94 \%(n=83 / 117), 17.09 \%,(n=20 / 117)$ Moderate and $11.96 \%,(n=14 / 117)$ Mild. In the placebo group it was Severe in $69.29 \%(\mathrm{n}=79 / 114), 16.66 \%,(\mathrm{n}=19 / 117)$ moderate and $14.03 \%$, $(n=16 / 114)$, mild with one $p>0.05$, without statistically significant difference.

Table I Sociodemographic characteristics of women from Armenia, Quindío with genitourinary syndrome of menopause

\begin{tabular}{|c|c|c|c|}
\hline & $\begin{array}{l}\text { Policresulene } \\
(n=|| 7)\end{array}$ & $\begin{array}{l}\text { Placebo } \\
(n=|| 4)\end{array}$ & $\mathbf{p}$ \\
\hline Age (years), mean $\pm S D$ & $56,72 ; p=8,35)$ & $57,32 ; p=7,49)$ & 0.43 \\
\hline Height (cms) & $158 ; p=0,76)$ & $160 ; p=0,85)$ & 0.71 \\
\hline Weight (kg) & $78.6 I ; p=I, 8)$ & $80.35 ; p=I, 5)$ & 0.68 \\
\hline BMI & $31.2 ; p=0,59)$. & $31,3 ; p=0,74)$. & 0.93 \\
\hline \multicolumn{4}{|l|}{ Race } \\
\hline Hispanics\% & 56.41 & 50.87 & 0.57 \\
\hline Afrocolombians $\%$ & 25.64 & 33.33 & 0.12 \\
\hline Indigenous\% & 17.94 & 15.78 & 0.45 \\
\hline \multicolumn{4}{|l|}{ Educational Level } \\
\hline Primary\% & 11.96 & 29.64 & 0.36 \\
\hline Secondary\% & 19.65 & 21.92 & 0.15 \\
\hline Technical\% & 43.58 & 40.35 & 0.18 \\
\hline Tertiary\% & 24.78 & 28.07 & 0.39 \\
\hline \multicolumn{4}{|l|}{ Civil Status } \\
\hline Divorced\% & 15.38 & 12.28 & 0.81 \\
\hline In union & 41.88 & 43.85 & 0.75 \\
\hline Married\% & 35.04 & 37.71 & 0.61 \\
\hline Widowed\% & 7.69 & 6.14 & 0.83 \\
\hline \multicolumn{4}{|l|}{ Origin } \\
\hline Rural\% & 20.51 & 17.54 & 0.13 \\
\hline Urban\% & 79.48 & 82.45 & 0.26 \\
\hline \multicolumn{4}{|l|}{ Occupation } \\
\hline Housewife\% & 32.47 & 35.96 & 0.53 \\
\hline Employed\% & 52.99 & 56.14 & 0.47 \\
\hline Retired\% & 14.52 & 7.89 & 0.23 \\
\hline \multicolumn{4}{|l|}{ Addictions\% } \\
\hline Smoking & 23.07 & 27.19 & 0.41 \\
\hline Alcohol\% & 78.63 & 79.82 & 0.29 \\
\hline Sedentarism\% & 76.06 & 68.42 & 0.14 \\
\hline
\end{tabular}


Related to the symptoms that affected the patients, the most frequent symptom was vaginal dryness, followed by dyspareunia and vaginal irritation in both groups (Figure 1). Regarding the relationship with the vulvo-vaginal symptoms and lower urinary tract findings associated to GMS, it was observed that $71.87 \%$ of the symptomatic women of the polcresulen group had 3, 22.91\% had 4, and 5.2\% presented 5 or more symptoms, while in the placebo group it was observed $70.17 \%$, $20.17 \%$ and $9.64 \%$, respectively, without statistically significant difference ( $p>0.05)$. The mean length of the presence of symptoms, at the time of treatment, was $12.65 \pm 4.79$ months (range between 3 and $60)$. In total, 29.91\%, $(n=35 / 117)$ of the women of the policresulen group and the $32.45 \%,(n=37 / 114)$ of those in the placebo group, had received some type of hormonal treatment at some time life after menopause. The evolution of the improvement and effectiveness of the therapy, in relation to the baseline situation, in each follow-up and at the end of the treatment is described in Table 2. At the end of the study it was observed, that efficacy in the policresulen group was $76.92 \%$, $(n=90 / 117)$, while in the placebo group it was $38.59 \%$, $(\mathrm{n}=44 / 117)$, with a statistically significant difference $(\mathrm{p}=0.003)$. There were significant differences between the two groups regarding the time for symptom reduction, being lower in the policresulen group (median of 4 weeks vs 8 weeks), $(\mathrm{p}<0.05)$. In the policresulen group tolerance was labeled as Excellent in $89.74 \%(n=105 / 117)$ and Good in $1.7 \%(\mathrm{n}=2 / 117)$, Regular in $2.56 \%(\mathrm{n}=3 / 117)$ and $\mathrm{Bad}$ at $5.98 \%$ $(\mathrm{n}=7 / 117)$, which implies a satisfactory tolerance in $91.45 \%$ of the women, compared to $92.98 \%$ of the placebo, without statistically significant difference $(\mathrm{p}=0.375)$. At the end of the study, the incidence of adverse effects was $10.25 \%(n=12 / 117)$ in the policresulen group, compared to $7.89 \%(n=9 / 114)$ in the placebo group; the local burning sensation being the most frequent $(4.27 \%)$, followed by the discharge of fragments of mucosal tissue $(2.56 \%)$ (Table 3$)$. In the placebo group there were fewer adverse effects, with no differences in both groups $(89.74 \%$ vs. 92,$1 ; p=0,27)$. In no case was there a need to interrupt the treatment before end of the research study.

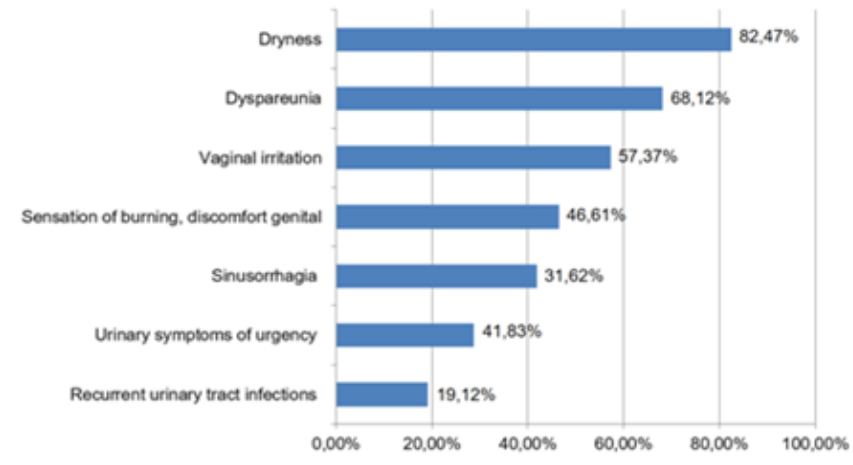

Figure I Symptoms of GSM reported in women from Armenia, Quindío.

Table 2 Percentage of the evolution of the improvement and effectiveness of the therapy

\begin{tabular}{llll}
\hline & $\begin{array}{l}\text { Policresulene } \\
(\mathbf{n}=1 \text { I 7) }\end{array}$ & $\begin{array}{l}\text { Placebo } \\
(\mathbf{n}=1 \text { I 1 })\end{array}$ & $\mathbf{P}$ \\
\hline Baseline & 0 & 0 & 0 \\
4 weeks & $25.64 \%$ & $13.15 \%$ & 0.024 \\
8 weeks & $63.24 \%$ & $29.82 \%$ & 0.018 \\
12 weeks & $76.92 \%$ & $38.59 \%$ & 0.003 \\
\hline
\end{tabular}

Table 3 Adverse effects

\begin{tabular}{|c|c|c|c|}
\hline & $\begin{array}{l}\text { Policresulene } \\
(n=117)\end{array}$ & $\begin{array}{l}\text { Placebo } \\
(n=1 \mid 4)\end{array}$ & $\mathbf{p}$ \\
\hline Vaginal dryness & $0,85 \%(n=1)$ & 0 & 0.11 \\
\hline $\begin{array}{l}\text { Localized burning } \\
\text { sensation }\end{array}$ & $4,27 \%(n=5)$ & $3,5 \%(n=4)$ & 0.54 \\
\hline $\begin{array}{l}\text { Discharge of mucus tissue } \\
\text { fragments }\end{array}$ & $2,56 \%(n=3)$ & $1,75 \%(n=2)$ & 0.75 \\
\hline Vaginal candidiasis & $1,7 \%(n=2)$ & $1,75 \%(n=2)$ & 0.84 \\
\hline Erythema with papule & $0,85 \%(n=I)$ & $0,87 ; p=1)$. & 0.93 \\
\hline
\end{tabular}

\section{Discussion}

The results of this investigation show an efficacy of $76.92 \%$ in the policresulen group $(n=90 / 117)$, while the placebo group reported $38.59 \%(n=44 / 117)$, a statistically significant difference $(\mathrm{p}=0.003)$. Tolerance was labeled as Excellent in $89.74 \%(n=105 / 117)$ and Good in $1.7 \%$, which reported a satisfactory tolerance in $91.45 \%$ of the women who received policresulen, compared to $92.98 \%$ of placebo, without statistically significant difference $(\mathrm{p}=0.375)$. At the end of the study, the incidence of adverse effects was $10.25 \%(n=12 / 117)$ in the policresulen group, compared to $7.89 \%(n=9 / 114)$ of the placebo group; being the local burning sensation the most frequent one $(4.27 \%$ vs. $3.5 \%$ ), followed by the discharge of mucosal tissue fragments $(2.56 \%$ vs. $1.75 \%)$, without statistically significant differences between groups $(89.74 \%$ vs. 92,$1 ; \mathrm{p}=0,27)$. In no case was there a need to interrupt the treatment before the end of the research study. Significant differences were found between the two groups regarding the time for symptom reduction, being lower in the policresulen group (median of 4 weeks vs 8 weeks), $(p<0.05)$. Policresulen as a selective effect on dead or pathologically altered tissues in the vagina, making them coagulate with a subsequent elimination, without affecting the healthy squamous epithelium. Its broad antimicrobial spectrum eradicates the pathogens of the vagina (bacteria, trichomonas and fungi), but increases the growth of Lactobacilli (Bacillus Döderlein) responsible for maintaining the physiological acidity of the vagina. It is useful to quickly diminish subjective complaints such as pruritus and leucorrhea. Reepithelialization is favored both by reactive hyperemia in the treated area and by the stimulation of the granulation of healthy tissues. ${ }^{12}$

The characteristics of the efficacy of policresulen make it an adequate alternative, in the treatment of the genitourinary syndrome of menopause, for of women who have contraindications for estrogen therapy have no interest in receiving said therapy, with higher rates of satisfaction than $3 / 4$ parts of the participating population. In this study, the feasibility and safety of the use of policresulen in postmenopausal women was demonstrated, with minimum adverse effects, that did not require any type of intervention or affected the continuation of therapy, making it attractive, safe and easy to use. In a study conducted in our country, Espitia et al. ${ }^{13}$ obtained an efficacy of $66.6 \%$ in the improvement of the symptoms of GMS using a lubricant with similar characteristics to our placebo, which is still lower than the $76,92 \%$ reported by policresulen in this study, however it is a population with similar socio-demographic characteristics, but with a smaller sample size, which may indicate differences in the results obtained by these researchers. The results of this study are comparable to the reports of a recent investigation by Espitia et al. ${ }^{14}$ where it concludes that the estriol used in combination with a lubricant, are effective to control the symptoms of GMS in $87 \%$ of women, making makes policresulen an attractive substance to consider as a choice in those women without interest for hormonal therapy. 
The characteristics of the non-hormonal therapies used in this study; one a condensation polymer of metacresolsulfonic acid (policresulen) and the other a water-based lubricant, suggest the possibility of a new alternative within the therapeutic arsenal for the treatment of the genitourinary syndrome of menopause; with higher satisfaction rates, placebo, in syndromic management. The main strength of the study is that it is the first research of its kind in Colombia, in addition to be the first one to evaluate the use of policresulen in the treatment of menopausal genitourinary syndrome, and to have had a sequential sampling with a significant participation of patients. The greatest weakness is that the results could not be compared with other studies of similar characteristics, since there is no scientific literature in this regard, in addition to an approximation of the costs incurred in each participant, which could be a limiting factor for its application in the general community.

\section{Conclusion}

The use of policresulen in women with genitourinary syndrome of menopause is effective for the management of the most frequent symptomatology. Although it is true that it is not the first therapeutic line of treatment, it should be considered for women with contraindications for estrogen therapy or for those who do not wish to receive it. There was a low presence of adverse effects at the dose used, however, these were tolerable and did not require the interruption of the medication. Additional studies, in larger populations, are required to establish the benefit in women with estrogen-dependent cancer or without interest in receiving estrogen therapy, as well as the costs that this represents.

\section{Financing}

The research was financed with the author's own resources.

\section{Acknowledgments}

To all participating women for allowing consent and for being part of the study; to my beautiful and admirable wife, Dr. Lilian Orozco Santiago, for always supporting and following my crazy investigations.

\section{Conflicts of interest}

The author declares there is no conflict of interest.

\section{References}

1. Portman DJ, Gass ML; Vulvovaginal Atrophy Terminology Consensus Conference Panel. Genitourinary syndrome of menopause: New terminology for vulvo-vaginal atrophy from the International Society for the Study of Women's Sexual Health and the North American Menopause Society. Menopause. 2014;21(10):1063-1068.
2. Espitia-De La Hoz FJ. Prevalence of genitourinary syndrome of menopause and impact on sexuality of women in Quindío (Colombia), 2013-2016. Rev Colomb Obstet Ginecol. 2018;69(4):249-259.

3. Espitia-De La Hoz FJ, Orozco-Gallego H. Estriol vs estrógenos conjugados de origen equino en el tratamiento del síndrome genitourinario de la menopausia. Ginecol Obstet Mex. 2018;86:117-126.

4. Simon JA, Nappi RE, Kingsberg SA, et al. Clarifying Vaginal Atrophy's Impact on Sex and Relationships (CLOSER) survey: emotional and physical impact of vaginal discomfort on North American postmenopausal women and their partners. Menopause. 2014;21(2):137-142.

5. Panay N. Genitourinary syndrome of the menopause--dawn of a new era? Climacteric. 2015;18(Suppl 1):13-17.

6. Moral E, Delgado JL, Carmona F, et al. Genitourinary syndrome of menopause: Prevalence and quality of life in Spanish postmenopausal women. The GENISSE study. Climacteric. 2018;21(2):167-173.

7. Karakoç H, Uçtu AK, Özerdoğan N. Genitourinary syndrome of menopause: effects on related factors, quality of life, and self-care power. Prz Menopause Rev. 2019;18(1):15-22.

8. Faubion SS, Sood R, Kapoor E. Genitourinary Syndrome of Menopause: Management Strategies for the Clinician. Mayo Clin Proc. 2017;92(12):1842-1849.

9. Espitia-De La Hoz FJ, Orozco Gallego H. Abordaje diagnóstico y terapéutico del síndrome genitourinario en la menopausia; actualización. Rev Med UCR. 2017;117:67-84.

10. Scorticati CH, Levati HA, Cartelli E. Utilizacion del ácido metacresolsulfonico, en cirugía prostática. Rev Arg Urol Nefrol. 1973;42(1):84-85.

11. Espinosa DJ. Analytical review of multicenter studies with polycresulene for hemorrhoidal pathologies. Acta Gastroenterol Latinoam. 2000;30(3):177-186.

12. Patetico AQ, Reyes LD, Rey-Matias CJ. Comparison of the operative and post-operative outcome between episiorrhaphy with and without application of policresulen solution. Philippine Obstetrical and Gynecological Society (POGS). 2016;40(2):12-19.

13. Espitia-De La Hoz FJ, Orozco Gallego H, Echeverri Ocampo LM. Terapia hormonal y no hormonal en la vaginitis atrófica posmenopáusica: cura y satisfacción a mediano y a largo plazo de los síntomas. Rev Col Men. 2016;22:8-17.

14. Espitia-De La Hoz FJ, Orozco Gallego H. Evaluación de la eficacia de dos terapias estrogénicas locales más un lubricante vaginal, para el control de los síntomas del síndrome genitourinario de la menopausia. Rev Investigaciones Andina. 2019;21:167-183. 